\section{British Council for Technical Education and Train- ing for Overseas Countries}

Is a written answer in the House of Commons on March 15, the Secretary for Technical Co-operation, Mr. D. Vosper, stated that he was setting up a Council for Technical Education and Training for Overseas Countries, under the chairmanship of Mr. F. J. Pedler, director of Unilever and joint managing director of the United Africa Company, to focus and intensify the British effort, both Governmental and non-Governmental, in this field. The Council, which would begin its work early in April, would have the following terms of reference: To give advice and expert assistance to the Government and others as may be required with the viow of promoting technical and commercial education and training for developing countries, and for this purpose, inter alia, (a) to furnish advice and information and to promote contacts between those concerned with such education and training in the United Kingdom and in developing countries; $(b)$ to promote, and where appropriate to undertake, the recruitment of staff for service overseas in this field; and $(c)$ to facilitate the training and education in the United Kingdom of trainees, teachers and others from developing countries. Mr. Vosper stated that the Council would take over the functions of the Council for Overseas Colleges of Arts, Science and Technology and also those of the Advisory Committee on Facilities for Commonwealth Trainees in the United Kingdom Trade and Industry. It would, he hoped, keep an appropriate balance between what was best done to provide assistance overseas and what should be done by way of technical training and education in Britain. His Department would draw heavily on the Council for advice, and he hoped that the Council would help to establish a close relation between what was done in technical education institutions and what was done in industry, and that it would explore ways of helping Govern. ments and industry to assess their needs, to put existing facilities to joint use and to co-operate in future developments. The other members of the Council are: Mr. A. P. Blair, Mr. G. Bosworth, Sir Christopher Cox, Miss I. S. Gibson, Mr. E. M. Hyde-Clarke, Sir Willis Jackson, Mr. J. C. Jones, Major-General C. Lloyd, Mr. J. Marsh, Mr. J. P. Martin-Bates, Mr. J. A. R. Pimlott, Dr. J. E. Richardson, Mr. C. S. Ritchie, Dr. E. A. Thompson, Mr. P. Trench, Dr. G. E. Watts, Mr. D. Winnard and Mr. R. E. Wood.

\section{Priroda}

Priroda ('Nature'), the Russian popular scientific journal, celebrates its fiftieth anniversary this year (Priroda, 1, 4; 1962). Since the appearance of the first number in January 1912, this journal has maintained through the years a very high standard of production and has acted as an intermediary between the various groups of specialists and a large public interested in the progress of science. It was started in 1912 by the chemist, L. V. Pisarzhevsky, and the biologist, V. A. Wagner, and with it were associated the best scientists of Russia, including A. N. Bach, V. I. Vernadsky, P. P. Lazarev, V. L. Komarov, L. S. Berg, N. S. Kurnakov, L. A. Tarasevich, and others. In 1918 Priroda passed under the ægis of the Academy of Sciences, one of its editors being A. E. Fersman, with a host of active collaborators, including N. I. Vavilov, A. F. Joffe, V. A. Obruchev, B. B. Polynov and many others. At the present time Priroda appears in monthly issues of about 120-130 pages (there are no advertisements), containing some ten articles dealing with the progress of the various sciences, reports on the progress of research and observations, reports of conferences and congresses, notes on the progress of science abroad, calendar of nature and short book reviews. 18,000 copies are printed. The price of each number is $70 \mathrm{kop}$.

\section{Control-an Expanding Industry}

DURING the poriod 1960-61, firms manufacturing control equipment made steady advances, and both potential and actual users of control equipment became somewhat more aware of the advantages in productivity, quality control and other situations offered by the new techniques. Nevertheless, industry at large is still paying little more than lip service to the value of automation. Some progress is being made, however, as is shown in Control, Industry Guide and Digest, 1962 (Pp. 214. London: Rowse Muir Publications, Ltd., 1961). Nearly 1,000 firms are listed; the present edition includes more than 200 extra companies, and, since about 100 firms dropped out, it appears that the industry has increased in size by something like 10 per cent. The edition is divided into eight sections: electromechanics; electrics and electronies; hydraulies and pneumatics; instrument; data processing; systems and applications; 'who's who'; and a buyers' guide.

\section{The Fraser River Archæological Project}

A shont progress article on the Fraser River archæological project, by Charles E. Borden, has recently been published by the Canadian Department of Northern Affairs and National Resources (Anthro. pological Papers of the National Museum of Canada. No. 1; December 29. 1961. Fraser River Archoelogical Project. By Charles E. Borden. Pp. 6 (2 plates). Ottawa: Queen's Printer). The work was carried out in 1960 by the University of British Columbia and the National Museum of Canada. There are two main zones, and they have yielded many artefacts. It is thought that the earliest cultural remains date back to about 6000 B.C., "near the end of the Pleistocene". Some leaf-shaped stone points have been unearthed, as well as choppers, drills, slate knives, pestles and mortors, saws, adzes, beads, etc. There are also some carved animal and human figurines. An excellent section is given showing the stratification and possible chronology of the site examined.

\section{Archæology in the Congo Republic}

The Institut des Pares Nationaux du Congo et du Ruanda-Urundi has recently published Part 6 of Exploration du Parc National Albert, an account of Jean de Heinzelin de Braucout's mission to the national park in 1950. (Fascicule 6: Le Paléolithique aux Abords d'Ishango. Par Jean de Heinzelin de Braucourt. Pp. 34+47 planches. (Bruxelles: Institut des Pares Nationaux du Congo et du Ruanda-Urundi, 1961.)) Most of this considerable work is occupied by full-page illustrations, of which there are 47. The text, only 34 pages, is concerned with a brief description of the localities and the position of the various terraces, and then with notes on the finds themselves. But the importance of the work lies in the excellent illustrations, which allow the student to study and judge for himself the various industries presented here. The artefacts are mostly, but not all, roughly made and pebble tools occur. They appear to be of early and middle Stone Age character. 